\title{
Fájdalomcsillapító-túlhasználathoz társuló fejfájás
}

\author{
Magyar Máté dr. ${ }^{1}$. Hajnal Boglárka dr. ${ }^{2}$ \\ Gyüre Tamás ${ }^{2}$ - Ertsey Csaba dr. ${ }^{1}$ \\ Semmelweis Egyetem, 'Általános Orvostudományi Kar, Neurológiai Klinika, \\ ${ }^{2}$ Szentágothai János Idegtudományi Doktori Iskola, Budapest
}

\begin{abstract}
A fájdalomcsillapító-túlhasználathoz társuló fejfájás a lakosság 1-2\%-át érinti. Bármely fájdalomcsillapító rendszeres, havonta legalább 10 napon történő szedése kiválthatja, ezért minden olyan esetben gondolni kell rá, amikor korábban is panaszos betegek fejfájásának gyakorisága - nagyobb mennyiségben szedett fájdalomcsillapítók mellett - megnő. A kórkép leggyakrabban a 40-50 éves nóket érinti: kockázatát növeli a dohányzás, az elhízás, a depresszió, valamint a szorongásos zavar. Kialakulásában biológiai (genetikai megalapozottság, neurokémiai és neurofiziológiai eltérések) mellett pszichológiai, illetve életvezetési tényezők, így a fejfájásokra vonatkozó anticipátoros szorongás, a fájdalom katasztrofizálása, az ezek miatti kényszeres gyógyszerszedő magatartás is fontos szerepet játszanak. A fájdalomcsillapító-túlhasználathoz társuló fejfájás kezelésének elengedhetetlen része a kiváltó szer megvonása, a megvonási tünetek (köztük a rebound fejfájás) kezelése, a hatásos preventív terápia bevezetése, a komorbid betegségek kezelése, valamint a betegek megfelelő oktatása és pszichés támogatása. Mivel a visszaesés esélye megfelelő kezelés mellett is $30-40 \%$ lehet, alapvető fontosságú a megelőzés, amelyben az alapellátás szerepét nem lehet eléggé hangsúlyozni. Orv. Hetil., 2015, 156(30), 1195-1202.
\end{abstract}

Kulcsszavak: fejfájás, fájdalomcsillapító-túlhasználat

\section{Medication-overuse headache}

Medication-overuse headache affects 1 to 2 percent of the population. Any kind of painkiller, if taken regularly at least 10 days per month can cause medication-overuse headache, and therefore the possibility of this headache has to be raised whenever a patient with a preexistent headache notices a significant increase in headache frequency during a period of frequent painkiller consumption. Medication-overuse headache is most prevalent in females between 40 and 50 years of age. Its main risk factors are smokig, obesity, depression, and anxiety. The pathomechanism of medication-overuse headache is complex, with a probable genetic propensity and other biological (neurochemical and neurophysiological), as well as psychological and behavioural factors (such as anticipatory anxiety, catastrophisation of pain and consequentially a compulsive painkiller use) contributing to its genesis. The prerequisite of successful treatment is the withdrawal of the overused substance, other necessary elements of the therapy include the treatment of withdrawal symptoms including rebound headache, the introduction of an effective preventative therapy, taking into consideration the highly prevalent comorbid disorders as well, and the education and psychological support of patients. As the relapse rate can be as high as 30 to $40 \%$ regardless of effective treatment, the prevention of medication-overuse headache is of paramount importance, and the role of general practitioners can hardly be overstated.

Keywords: headache disorders, medication-overuse headache

Magyar, M., Hajnal, B., Gyüre, T., Ertsey, Cs. [Medication-overuse headache]. Orv. Hetil., 2015, 156(30), 11951202 .

(Beérkezett: 2015. május 9.; elfogadva: 2015. június 11.) 


\section{Rövidítések}

CGRP = kalcitonin gén rokon peptid; $\mathrm{DHE}=$ dihidroergotamin; FTTF = fájdalomcsillapító-túlhasználathoz társuló fejfájás; NSAID = nem szteroid gyulladáscsökkentő

A fájdalomcsillapító-túlhasználathoz társuló fejfájás (FTTF; angolul: medication-overuse headache - $\mathrm{MOH}$ ) olyan krónikus betegség, amely egyszerű analgetikumok, triptánok vagy más akut fejfájásellenes szerek túlzott mértékű fogyasztásának következményeként alakul ki [1]. A Nemzetközi Fejfájás Társaság (IHS) által összeállított nemzetközi fejfájás-klasszifikáció legújabb, harmadik kiadása - az ICHDIII-beta - alapján FTTF diagnózisa állítható fel akkor, ha egy korábban primer fejfájásban szenvedő beteg havi legalább 15 napon tapasztal fejfájást, és ez az állapot fejfájáscsillapítók rendszeres, több mint 3 hónapon át tartó túlhasználata mellett alakult ki [2]. A kritériumrendszer az FTTF további specifikus alcsoportjait különíti el, mint az egyszerú analgetikum- (acetilszalicilát, paracetamol vagy más NSAID) fogyasztást követő FTTF; a koffeinnel, opioiddal vagy barbituráttal kombinált analgetikumok által kiváltott FTTF; az ergotok, triptánok és opioidok túlfogyasztása miatt kialakuló FTTF. Ezen csoportok legtöbbjénél a kritikus gyógyszerszedési gyakoriság küszöbértéke havi 10 nap; kivételt jelent az egyszerú analgetikumok fogyasztása mellett kialakuló FTTF, ahol a küszöbérték havi 15 nap.

Horton és munkatársai már több mint fél évszázaddal ezelőtt felhívták a figyelmet a jelenségre, hogy egyes akut, fejfájás kezelésére alkalmazott gyógyszerek túl gyakori használata a primer betegség progressziójához vezet [3]. Ezt a megfigyelést késóbb többen megerősítették különböző hatásmechanizmusú rohamgyógyszerek esetén $[4,5]$. A migrén kezelésére ma leghatékonyabbnak tartott triptánok forgalomba hozatala után 4 évvel, 1994-ben jelent meg az első esettanulmány a triptán indukálta FTTF-ról [6]. Azt, hogy nem véletlen egybeesésrôl van szó, több nagy populáción elvégzett epidemiológiai vizsgálat is igazolta, így például Norvégiában, a több mint 51000 alany bevonásával készült Head-HUNT tanulmányban a krónikus fejfájás hétszer nagyobb valószínúséggel fordult elő az analgetikumot legalább egy hónapon keresztül napi vagy majdnem napi rendszerességgel szedők körében, mint a gyógyszert nem szedők között [7].

A krónikus mindennapos fejfájás prevalenciája világszerte átlagosan 4-5\% [8]. A krónikus mindennapos fejfájásban szenvedő egyének egyharmadánál észlelhetőek az FTTF diagnosztikus kritériumai. Az FTTF prevalenciája az általános populációban 1-2\% körüli (nőknél $2,6 \%$, férfiaknál $0,19 \%$ ) [8], ugyanakkor a fejfájás-ambulanciák beteganyagának akár 30-50\%-át adja [9]. Jellemzően a 40-50 év közötti korosztályban a leggyakoribb [10]. Részben ezzel, részben gyakoriságával magyarázható, hogy az FTTF társadalmi szinten a legköltségesebb neurológiai betegségek közé tartozik [11]. A költségek túlnyomó része úgynevezett indirekt költség, amely a gyakori fejfájások miatt kieső vagy csökkent produktivitású munkából adódik. Ugyanakkor az FTTF az egyén számára is komoly tehertétel, és jelentős mértékú életminőség-romláshoz vezet. Mindezek alapján hazánkban 100 000-200 000 betegre számíthatunk, és kijelenthető, hogy a kórkép jelentős terhet ró a hazai egészségügyre és a gazdaságra.

\section{Általános jellemzők}

Mint fentebb már utaltunk rá, az FTTF-betegek többsége 40-45 év körüli nő [10]. Egy több mint 2600 beteg adatait feldolgozó metaanalízis szerint a leggyakoribb kiindulási fejfájástípus a migrén (65\%), míg 27\%-nak volt korábban tenziós típusú fejfájása; a betegek $8 \%$-ának kevert (migrén és tenziós) fejfájása vagy egyéb önálló fejfájása (például cluster fejfájás) volt az FTTF kialakulása előtt [12]. Ugyanakkor nemcsak elsődleges fejfájás vezethet FTTF kialakulásához, hanem a poszttraumás és néhány egyéb másodlagos fejfájás is $[13,14]$. Az FTTF prognózisa szempontjából kedvezőbb, ha a megelőző fejfájás migrén: más primer fejfájástípusokból kialakuló FTTF esetén a prognózis rosszabb [10]. A kialakuló terápiarefrakteritás előtt általában a fejájás gyakorisága és erőssége megnövekszik, a rohamok kiváltásáért felelős ingerekkel szembeni érzékenység fokozódik.

\section{FTTF kialakulásához vezető szerek}

Az FTTF kialakulásához vezető, leggyakrabban alkalmazott szerek az egyszerú analgetikumok, illetve ezek kombinációja koffeinnel, amelyet a gyakorisági sorrendben a triptánok követnek. Hazánkban leggyakrabban a koffeinnel, illetve szintetikus morfinszármazékokkal kombinált analgetikumok abúzusa felelős a panaszokért [15]. Ugyanakkor a gyógyszerekhez való hozzájutás eltérései miatt például az Amerikai Egyesült Államokban jelentős a butalbitalhasználat szerepe, amely már havi 5 napi bevétel esetén is FTTF kialakulásához vezet [16], míg Indiában a kórkép hátterében legtöbbször ergotamintúlhasználat áll [17]. Az eddigi vizsgálatok alapján a migrénes rohamban akut szerként alkalmazott CGRP-antagonisták egy új csoportjáról feltételezhető, hogy nem vezet FTTF kialakulásához, de ezek a készítmények egyéb mellékhatásaik miatt végül nem kerültek forgalomba [1]. Így elmondható, hogy a jelenleg használt valamennyi fájdalomcsillapító gyakori alkalmazása mellett fennáll az FTTF kialakulásának veszélye.

\section{Klinikai megjelenés}

A fájdalomcsillapító-túlhasználathoz társuló fejfájás diagnózisának megállapításakor nem a fejájás minősége, hanem inkább annak mennyisége, átfogóan véve a fejfá- 
jás mintázata a meghatározó, valamint annak kapcsolata az alkalmazott gyógyszerrel [18]. A betegek gyakran a nyaki területen megjelenő fájdalom miatt fordulnak orvoshoz, ez a nyakfájdalom az akut migrénellenes szer elhagyása után elmúlhat [18]. Mivel a gyógyszerbevételek közötti intervallum az éjszaka folyamán a legnagyobb, a fejájás gyakran ébredés után, a reggeli órákban a legerősebb, jelezve ezzel az analgetikum-, triptán- vagy opioidmegvonás jelenségét. A fájdalomcsillapítók túlzott használatához társuló fejfájás klinikai jellemzői nagymértékben függenek attól, hogy a beteg milyen farmakológiai tulajdonságokkal rendelkező szert fogyasztott: korábban migrénes betegek ergot- vagy analgetikumtúlhasználat esetén a migrén mellett gyakori tenziós jellegú fejfájásokat észleltek, míg a triptánfogyasztók esetén a migrén frekvenciájának fokozódása volt megfigyelhető [10]. A gyógyszertípustól függ az FTTF kialakulásához szükséges idő is: legrövidebb idő alatt (átlagosan 1,7 év) a triptánok vezetnek FTTF kialakulásához, míg hosszabb idő alatt alakul ki FTTF ergotszármazékok (2,7 év), illetve egyszerü analgetikumok (4,8 év) használata esetén [10]. Hasonlóan alakul a kórkép kialakulásához szükséges gyógyszerbevételi gyakoriság is: a vizsgálatok alapján a legkisebb átlagos dózis a triptánok használata során volt (18 dózis/hó), ennél nagyobb volt az ergotok (37 dózis/hó) és a legnagyobb az egyszerú analgetikumok (114 dózis/hó) alkalmazása esetén [10, 19].

A fájdalomcsillapítók túlzott használata esetén kialakuló fejfájáshoz az epizodikus fejfájáshoz képest több kísérő tünet és komorbid állapot (gyengeség, hányinger, fáradékonyság, ingerlékenység, depresszió, koncentrációs és memóriazavar [20], szorongás és hangulatzavar [21], a koffeintartalmú analgetikumok által kiváltott alvászavar) társul [18]. Azon ismert tény, hogy a krónikus fejfájás gyakran társul krónikus hátfájdalommal [22], fibromyalgiával [23], arcfájdalommal [24] és temporomandibularis zavarokkal [25], illetve a krónikus fejfájás és a musculoskeletalis fájdalom közötti bizonyított, kétirányú kapcsolat azt sugallják, hogy a fejfájás és a fájdalom krónikussá válásában az egész központi fájdalomérzékelő rendszer szerepet játszik [10]. Gyakorlati szempontból lényeges a komorbid állapotok feltárása és kezelése, ez ugyanis az FTTF prognózisára is kihatással lehet.

\section{Kockázati tényezők}

A fájdalomcsillapító-túlhasználathoz társuló fejfájás kialakulásának legfontosabb kockázati és egyben kiváltó tényezője maga a túlzott mennyiségű gyógyszerfogyasztás [10]. Ez különösen abban az esetben jelentős, ha migrénben vagy tenziós fejfájásban szenvedő betegek szednek rendszeresen, nagy adagban fájdalomcsillapítókat [10], még akkor is, ha más betegség miatt szedik ezeket a gyógyszereket [26]. Jóval ritkábban, de előfordul FTTF olyan betegek körében is, akik korábban nem voltak fejfájósok, de családjukban többeknek volt migrénje [27]. Nem elhanyagolható a pszichológiai kockázati té- nyezők szerepe sem: az anticipátoros szorongás, illetve a hangulatzavar is hozzájárulnak a gyógyszerek túlzott mértékű fogyasztásának kialakulásához, illetve annak fenntartásához. Egy összehasonlító vizsgálat szerint az FTTF-betegek hangulatzavarra vonatkozó kockázata körülbelül ötször, generalizált szorongásra való kockázata hatszor akkora volt, mint a migréneseké [28], és e betegségek a kórkép kialakulását megelőzték. Ugyanebben a vizsgálatban az FTTF-betegek pszichoaktív szerhasználatának kockázata csaknem nyolcszorosa volt a migrénesekének: a szerhasználat a betegek 90\%-ában korábbi keletû volt, mint az FTTF. További rizikófaktor a dohányzás és a fizikai inaktivitás, amelyek több mint kétszeresére emelik az FTTF kialakulásának kockázatát [29]. Az obesitas a fájdalomcsillapító-túlhasználathoz társuló fejfájás kockázatát mintegy háromszorosára emeli [30]. Az FTTF iránti, fejfájásoktól független örökletes fogékonyság lehetősége epidemiológiai bizonyítékok alapján vethető fel: a kórkép kialakulásának kockázata háromszoros abban az esetben, ha a családban elöfordult drogvagy alkoholabúzus [31], illetve négyszeres, ha az egyik családtag FTTF-beteg [31].

\section{Patomechanizmus}

Az FTTF patofiziológiája és a létrehozásában szerepet játszó folyamatok csak részben ismertek. Jelen, humán megfigyeléseken és állatkísérleteken alapuló elképzeléseink szerint az FTTF kialakulásában biológiai (genetikai, neurokémiai és neurofiziológiai), illetve pszichológiai és életvezetésbeli tényezők is szerepet játszanak. A genetikai tényezőkre utalnak a fentebb részletezett epidemiológiai adatok mellett kisebb betegcsoportokban végzett vizsgálatok, amelyek több gén szerepét vetették fel. A dopamintranszporter gén (DATl) 10-es alléljának polimorfizmusa az FTTF iránti fogékonyságot növelheti [32], a BDNF gén és a wolframin gén (WFS1) polimorfizmusai a gyógyszerfogyasztás mértékét befolyásolhatják [33, 34], míg a COMT és SLC6A4 gének a terápiára adott válaszra lehetnek hatással [35].

A fájdalomcsillapító-túlhasználathoz társuló fejfájás hátterében álló neurokémiai tényezők közül elsődlegesek az alkalmazott fájdalomcsillapítók biokémiai tulajdonságai, de lényeges az alkalmazott gyógyszer dózisa, valamint a gyógyszerhasználat időtartama is. A migrénroham kezelésére alkalmazott gyógyszerek gyakori adása olyan idegrendszeri változásokon (neuronalis plaszticitás) keresztül vezet gyakoribb rohamokhoz, amelyek fokozhatják a migrén triggerei iránti érzékenységet [36]. Az egyik ilyen változás valószínúleg az, hogy a gyakori rohamgyógyszer-használat a centrális szerotonerg rendszer tartós aktiválódásához vezet, ami receptor-downregulációt okoz, és végső soron a fájdalomérzés modulációjában részt vevő szerotonerg pályák csökkent múködését eredményezi. Figyelmet érdemel, hogy nemcsak a szerotonerg támadáspontú rohamgyógyszerek (triptánok, illetve ergotszármazékok) esetén írták le ezt a jelenséget, 
hanem például paracetamol kísérletes adása kapcsán is [37]. Az idegrendszer megváltozott érzékenységére, a környezeti ingerek feldolgozásának zavarára utalnak azok az elektrofiziológiai vizsgálatok is, amelyek FTTFbetegek körében a habituáció zavarát igazolták [38]. Más vizsgálatok szerint FTTF-betegekben a fájdalomingerek repetitív alkalmazása centrális szenzitizációhoz vezet, azaz a fájdalomérzés a központi idegrendszer fájdalomfeldolgozó struktúráinak múködészavara miatt fokozódik, illetve tartóssá válik [39]. Morfológiai [40] és funkcionális [41] agyi képalkotó vizsgálatok eredményei szintén alátámasztják a fájdalom érzékelésében részt vevő agyi hálózat múködészavarát. Emellett az orbitofrontalis kéreg múködészavarát is kimutatták [42], hasonlóan más, szerfüggőséggel járó kórképekhez.

Egyre több adat utal rá, hogy a fájdalomcsillapító-túlhasználathoz társuló fejfájás kialakulásában pszichológiai és életvezetési tényezőknek is jelentős szerepe van. Fontos tényező a fejfájásokra vonatkozó anticipátoros szorongás és a fájdalom katasztrofizálása: a betegek félnek a fájdalom súlyosságától, illetve a munkateljesítményüket rontó fejfájásrohamok miatt a munkahelyük elvesztésétől, így a fejfájás első jelének észlelésekor, már a rohamot megelőzően gyógyszert vesznek be, ezzel növelve a gyógyszerbevételi gyakoriságot, és így meghaladják az FTTF kialakulási küszöbét [43]. A fejfájástól való félelem (cephalgiaphobia) klinikai jellemzóit tekintve kimeríti a specifikus fóbiák DSM-IV. szerinti kritériumait [44]. Későbbi tanulmányokban megállapítást nyert, hogy a cephalgiaphobia kockázata a migrén gyakoriságával párhuzamosan nő [45], illetve viselkedésterápiás módszerekkel csökkenthető, amivel párhuzamosan a fejájás javul [46]. Más megfigyelések arról számolnak be, hogy FTTF-betegek körében a szubklinikus obszesszív-kompulzív zavar gyakoribb, mint epizodikus vagy krónikus migrénesek között [47], ami egyrészt növelheti a gyógyszerbevétel esélyét, másrészt aláhúzza az orbitofrontalis kéreg szerepét a kórkép kialakulásában.

\section{Kezelés}

A fájdalomcsillapítók túlzott használatához társuló fejfájás kezelésének célja - az egyén detoxifikálásán és így a fejfájás gyakoriságának és erősségének csökkentésén túl az akut, illetve a profilaktikus szerekre való érzékenység fokozása [1]. A terápia megkezdése előtt fontos a betegek részletes kivizsgálása a másodlagos (tüneti) fejájás kizárásának céljából. A fájdalomcsillapító-túlhasználathoz társuló fejfájás kezelésének speciális terápiás követelményei miatt fontos a kórkép elkülönítése a krónikus mindennapos fejfájás többi altípusától. A részletes belszervi és neurológiai vizsgálat mellett legtöbb esetben pszichológiai vizsgálat is szükséges, mivel a kórkép gyakran jár magatartászavarral, lefolyását és kezelését pedig nagymértékben befolyásolja szorongás, depresszió és más neuropszichológiai társbetegségek fennállása.
A fájdalomcsillapító-túlhasználathoz társuló fejfájás kezelésének lépései közé a kiváltó szer (fájdalomcsillapító) megvonása, a megvonás következtében fellépő tünetek, köztük a rebound fejfájás kezelése, a gyógyszeres profilaxis, valamint a betegek megfelelő oktatása és pszichés támogatása tartoznak. Fontos a betegek gondos felvilágosítása, illetve a kezeléssel kapcsolatban reális célok kitűzése. Így azt is tisztázni kell, hogy a fejfájás javulása általában csak néhány hetes kezelés után következik be, ezért a betegek változó ideig panaszosak maradhatnak. Ugyanakkor több klinikai vizsgálat igazolja, hogy a fenti elemekre épülő kezelés eredményes [48, 49] és javítja a betegek életminőségét [50].

\section{Megvonásos terápia}

A fájdalomcsillapítók megvonása történhet hirtelen, illetve fokozatosan is. Egyetlen prospektív randomizált tanulmány sem hasonlítja össze a hirtelen történő megvonás és a fokozatos leépítés eredményeit. A legtöbb fejfájásszakértő a szer hirtelen megvonásának módszerét javasolja [51], ugyanakkor az opioidok, barbiturátok és legfóképpen a benzodiazepinek esetében az elvonási tünetek csökkentése érdekében a szer fokozatos megvonása ajánlott. A megvonás fő tünetei közé tartozik a fejfájás rosszabbodása, a hányinger, hányás, hypotensio, tachycardia, alvászavar, nyugtalanság, szorongás és az idegesség. Ezek a tünetek általában 2-10 napig tartanak, de akár 3-4 héten keresztül is fennállhatnak. Fontos a betegek szoros követése (ambuláns kontrollokon túlmenően például rendszeres telefonos kapcsolattartással). A megvonásos terápia kimenetele a fejfájós napok számát, illetve a fejfájás javulását figyelembe véve nem különbözik jelentősen abban az esetben, ha a beteg követését neurológus helyett az elsődleges ellátásban dolgozó orvos végzi [1]. Mivel a járó betegként történő ellátás olcsóbb, és a motivált betegek csoportjánál ugyanolyan hatásos, mint a kórházi kezelés, a nyugat-európai ajánlások ezt az eljárást részesítik előnyben. Ugyanakkor az opioidok, a barbiturátok vagy a benzodiazepinek túlzott mértékű használata, valamint pszichés problémák, súlyos társbetegségek fennállása, súlyos megvonási tünetek (például hányás, status migrainosus) vagy a korábbi gyógyszerelvonás sikertelensége esetén kórházi kezelést javasolnak [52].

\section{A rebound fejfájás és megvonási tünetek kezelése}

Általános megfigyelés, hogy a fájdalomcsillapítók szedésének felfüggesztését követően a korábbi fejfájás felerősödik (rebound fejfájás), illetve hozzá a beteg számára további tehertételt jelentő tünetek és panaszok (hányinger, hányás, szédülés, verejtékezés, tachycardia, kézremegés, nyugtalanság, alvászavar stb.) társulnak. E tünetek kezelése nélkül nem várható, hogy a betegek kitartsanak a 


\begin{tabular}{|c|c|c|c|}
\hline Hatóanyagcsoport & Ajánlott egyszeri adag & Maximális napi adag & Leggyakoribb mellékhatások \\
\hline \multicolumn{4}{|l|}{ Fájdalomcsillapitók } \\
\hline Acetilszalicilát tabletta vagy por & $1000 \mathrm{mg}$ & $4000 \mathrm{mg}$ & Fekélybetegség, gyomorvérzés \\
\hline Paracetamol tabletta & $1000 \mathrm{mg}$ & $4000 \mathrm{mg}$ & Vese- és májtoxicitás \\
\hline Naproxen tabletta & $500-1000 \mathrm{mg}$ & $1500 \mathrm{mg}$ & Fekélybetegség \\
\hline Ibuprofen tabletta vagy por & $400-600 \mathrm{mg}$ & $3200 \mathrm{mg}$ & Fekélybetegség \\
\hline Diclofenac tabletta vagy por & $50-100 \mathrm{mg}$ & $200 \mathrm{mg}$ & Fekélybetegség \\
\hline Indometacin kapszula vagy kúp & $75-100 \mathrm{mg}$ & $200 \mathrm{mg}$ & Fekélybetegség, szédülés \\
\hline \multicolumn{4}{|l|}{ Antiemetikumok (adjuváns kezelésre) } \\
\hline Metoclopramid tabletta vagy injekció & $10-20 \mathrm{mg}$ & $60 \mathrm{mg}$ & Neuroleptikus szindróma \\
\hline Domperidon tabletta vagy injekció & $10-20 \mathrm{mg}$ & $80 \mathrm{mg}$ & Neuroleptikus szindróma \\
\hline \multicolumn{4}{|l|}{ Triptánok } \\
\hline Sumatriptan tabletta & $50-100 \mathrm{mg}$ & $200 \mathrm{mg}$ & Vasoconstrictio \\
\hline Zolmitriptan tabletta & $2,5 \mathrm{mg}$ & $10 \mathrm{mg}$ & Vasoconstrictio \\
\hline Eletriptan tabletta & $20-40 \mathrm{mg}$ & $80 \mathrm{mg}$ & Vasoconstrictio \\
\hline Frovatriptan tabletta & $2,5 \mathrm{mg}$ & $5 \mathrm{mg}$ & Vasoconstrictio \\
\hline Sumatriptan orrspray & $20 \mathrm{mg}$ & $40 \mathrm{mg}$ & Vasoconstrictio \\
\hline Sumatriptan injekció & $6 \mathrm{mg}$ & $12 \mathrm{mg}$ & Vasoconstrictio \\
\hline
\end{tabular}

javasolt kezelés mellett. Ugyanakkor - mivel gyógyszertani típustól függetlenül minden fájdalomcsillapító hozzájárulhat az FTTF fenntartásához - fontos a fejfájás kezelési stratégiáit megtervezni, és a beteggel is egyértelmúsíteni. A választott rohamgyógyszer típusát és adagját úgy célszerú megválasztani, hogy egyrészt igazodjon a primer fejfájás típusához, másrészt ne abból a hatástani csoportból kerüljön ki, mint a korábban túlfogyasztott rohamgyógyszer, illetve hogy minél kisebb mértékben járuljon hozzá a fejfájások fenntartásához. Így például migrénes jellegű fejfájásaikra korábban ergotszármazékokat használók esetén megfelelő adagú, egykomponensű NSAID-ek vagy triptánok alkalmazandók, míg triptántúlhasználat esetén elsősorban NSAID-ek. Az opiát- vagy barbituráttartalmú készítmények kerülendők. Alapelv, hogy enyhe (a tevékenységet nem befolyásoló) fejfájásra ne használjunk fájdalomcsillapítót. Súlyos rohamoknál triptán vagy a hazánkban jelenleg nem hozzáférhető dihidroergotamin (DHE) alkalmazható legfeljebb heti 2 alkalommal és kevesebb, mint havi 10 napon át [49]. Migrénre jellemző vonásokat mutató fejfájások esetén a migrén rohamgyógyszerei alkalmazhatóak (1. táblázat). Amennyiben a fejfájáshoz hányinger vagy hányás társul, de a gyorsabb hatás elérésének érdekében is célszerú parenteralis vagy per rectum alkalmazható készítményeket választani. Mivel a megvonásos fejfájás kezelésére használt legtöbb szer önmagában FTTF kialakulását eredményezheti, ezért több ajánlás a kortikoszteroidok alkalmazását javasolja: ezek hatékonyságát több vizsgálat igazolta $[53,54]$. A kezelés eredményei- nek értékelése és a terápia betartása céljából fontos a fejfájásnapló vezetése, amelyen a rohamgyógyszerek adagja is feltüntetendő [18].

$\mathrm{Az}$ elvonási tünetek kezelésére ajánlott lehetőségek között szerepel a parenteralis folyadékpótlás, hányinger esetén metoclopramid vagy domperidon [55], nyugtalanság esetén benzodiazepinek, illetve esetlegesen neuroleptikumok (például chlorpromazin) adása [56].

\section{Profilaktikus terápia}

A fejfájás prevenciója a kezelési stratégia fontos eleme, célja a fejfájás gyakoriságának és az akut szerek használatának csökkentése. Megkezdését a gyógyszermegvonással egy időben vagy akár már ezt megelőzően is ajánlják [9]. A Nemzetközi Fejfájás Társaság fejfájás-profilaxisra vonatkozó ajánlása alapján a terápia sikerességéről akkor beszélhetünk, ha a fejfájós napok száma több mint 50\%-kal csökkent. FTTF esetén alkalmazandó, specifikus preventív kezelésről szóló tanulmányok csak elvétve állnak rendelkezésre, ezért a preventív szer kiválasztásánál a primer fejfájás típusa (migrén vagy tenziós típusú), a szer mellékhatásai, a társbetegségek (amelyek között nagy gyakoriságuk miatt kiemelt figyelmet érdemelnek a hangulatzavarok és más pszichés kórképek), illetve a beteg igényei és a megelőző terápiás tapasztalatok a mérvadóak. A topiramát hatékonyságát nyílt vizsgálatok után placebokontrollált vizsgálatok is igazolták krónikus migrénhez társuló gyógyszer-túlfogyasztás esetén $[57,58]$. Több nyílt klinikai vizsgálat igazolta a valproát, illetve 
amitriptilin pozitív hatását is [59]. Az onabotulinumtoxin-A hatékonyságát a krónikus migrénes betegek körében végzett PREEMPT vizsgálat utólagos elemzése bizonyította, amelynek során a kezelés előtt a fájdalomcsillapítók túlzott használatához társuló fejájás kritériumait teljesítő betegek adatait külön elemezték [60]. Két kezelést követően a betegek 46\%-a tapasztalta a fejfájások gyakoriságának legalább 50\%-os csökkenését. A topiramát, valproát és a hagyományos gyógyszerek, mint a béta-blokkolók vagy triciklikus antidepresszánsok használata esetén is érdemes alacsonyabb kezdő dózis után a terápiás dózist fokozatosan felépíteni: ezzel csökkenthetők a mellékhatások, és javulhat a compliance. Amenynyiben pszichés, illetve egyéb komorbiditás is fennáll, ennek megfelelő kezelése a profilaktikus terápia hatékonyságát növelheti.

\section{A kezelés nem gyógyszeres elemei}

A fájdalomcsillapítók túlzott használatához társuló fejfájás kezelését tárgyaló különböző ajánlások egyetértenek azzal, hogy a gyógyszermegvonáson és a megfelelő roham-, illetve profilaktikus kezelésen túl szükséges a betegek gondos felvilágosítása, részben együttmúködésük megnyeréséhez, részben a kezelés során várható nehézségekre (rebound fejfájás, megvonási tünetek) való felkészüléshez. Emellett fontos a betegek pszichológiai vizsgálata, szükség esetén intervencióval, illetve fontos a provokáló tényezők, köztük az életvitellel kapcsolatos tényezők azonosítása. Mindezen elemek jelentősen hozzájárulhatnak a kezelés sikeréhez: egy hároméves utánkövetés során a csak gyógyszeres kezelésben részesülők 40\%-a, míg a gyógyszeres kezelés mellett viselkedésterápiában is részesülők 13\%-a tapasztalt visszaesést [61]. A gyógyszeres kezeléshez hasonlóan az alkalmazandó pszichológiai intervenciók tekintetében sincs egységes, nagy betegszámú vizsgálatokra támaszkodó ajánlás. Az utóbbi időben egyre többen ajánlják multidiszciplináris fejfájásterápiás programok alkalmazását. Ezek olyan intenzív, általában 5 napos programok, amelyek során a neurológiai vizsgálat mellett pszichológus, szükség esetén pszichiáter, fizioterapeuta is megvizsgálja a beteget, és a neurológus által javasolt gyógyszeres kezelést a találtak függvényében egészítik ki egyéb elemekkel. A komplex program magába foglalja a fejfájásokkal kapcsolatos részletes oktatást, a fájdalomcsillapító-megvonást, a gyógyszeres roham- és profilaktikus kezelést, relaxációt, viselkedésterápiás üléseket, fizioterápiás kezeléseket, aerob gyakorlatok szakértő segítségével történő végzését, valamint részletes életvezetési tanácsadást. A multidiszciplináris megközelítés hasznosságát több tanulmány igazolta. Egy német vizsgálatban 56 FTTF-beteg közül 51-nek volt sikeres a kezelése [62]. Egy másik vizsgálat során a komplex kezelési programba bevont betegek 33,8\%-ának volt FTTF-je, ami a kezelési időszak végére 1,6\%-ra csökkent, az FTTF miatt kezelt betegek fejfájás- gyakorisága pedig átlagosan havi 18,8 napról 10,9 napra csökkent [63].

\section{Prognózis}

A fájdalomcsillapítók túlzott használatához társuló fejfájás kimenetele döntően a megfelelő megvonásos terápia alkalmazásától, a komorbid állapotoktól, valamint a beteg motiváltsági szintjétől függ. A relapsusarány, más addiktív betegségekhez hasonlítva, alacsonynak tekinthető, 1 év után 30-40\% körüli, függetlenül attól, hogy ambuláns vagy kórházi ellátás keretein belül történt az elvonás. A legtöbb visszaesés a megvonást követő 1 éven belül történik [64]. A visszaesés esélyét növeli, ha a kiindulási fejfájás tenziós fejfájás vagy kevert (tenziós és migrénes) fejfájás volt. A további kockázati tényezők közé tartozik a férfi nem, a hosszú betegségtartam, kombinált analgetikumok használata a megvonásos terápiát követően, illetve az FTTF-et kiváltó szer ismételt alkalmazása $[65,66]$.

\section{Prevenció}

A fájdalomcsillapítók túlzott használatához társuló fejájás prevenciója a fejfájás megszüntetésére javasolt rohamgyógyszer első felírásakor kezdődik. Fontos már az első gyógyszer felírása során a szer mennyiségének gondos kiszámolása, a gyógyszerszedési gyakoriság és a következő kontroll időpontjának meghatározása. A szóbeli tájékoztatás vagy az oktatóbrosúrák jelentős mértékben segítik a túlfogyasztás megelőzését [67]. A meglévő vagy az anamnézisben szereplő szorongás, kényszeres gyógyszerszedés, valamint a valós addikció mind olyan figyelmeztető jelek, amelyeket a gyógyszert felíró orvosnak figyelembe kell vennie. Általánosságban elmondható, hogy a betegeket óvni kell bármely fájdalomcsillapító heti 2 napnál gyakoribb használatától. Egyes gyógyszerek esetén a tứréshatár még kisebb. Az ergotamin maximális adagja rohamonként $4 \mathrm{mg}$, hetente $8 \mathrm{mg}$ és havonta legfeljebb $20 \mathrm{mg}$ lehet, a triptánok havi maximális adagja 10 adag lehet. A barbiturát-, koffein-, kodein-, benzodiazepintartalmú és más kombinált szerek elkerülése szintén a prevenció fontos tényezői [10].

A rohamkezelés korlátozása mellett a prevenció lényeges eleme a fejfájás-profilaxis. Gyakori fejfájások esetén még abban az esetben is indokolt a profilaktikus (a fejfájások gyakoriságának csökkentését célzó) kezelés, ha a rohamgyógyszerek hatékonyak: a jól megválasztott profilaktikus szer mellett ugyanis jelentősen csökkenhet a fájdalomcsillapító-igény, ezzel csökkenthető az FTTF kialakulásának esélye is. A rohamgyógyszerek és/vagy a profilaktikus kezelés beállításához célszerü lehet neurológiai vagy fejfájás-ambulancia segítségét kérni.

Mivel a fájdalomcsillapítók túlzott használatához társuló fejfájás gyakori kórkép, és jelentős társadalmi-gazdasági következményekkel bír, a vele kapcsolatos információk mind az egészségügyi dolgozók, mind a lakosság 
számára lényegesek. A lakosság körében végzett széles körű felvilágosítással az FTTF-esetek előfordulási gyakorisága csökkenthető lenne [59]. Az orvosi gyakorlatban az FTTF lehetőségét fel kell vetni minden olyan beteg esetén, aki mindennapos vagy csaknem mindennapos gyakoriságú fejfájást panaszol. A megelőzés fontos eleme lehet a praxisunkban (fejfájások, illetve egyéb betegségek miatt) gondozott betegek fájdalomcsillapító-fogyasztásának nyomon követése. Mivel a visszaesés esélye megfelelő kezelés mellett is magas, alapvető fontosságú a megelőzés, amelyben az alapellátás szerepét nem lehet eléggé hangsúlyozni.

Anyagi támogatás: A közlemény megírása, illetve a kapcsolódó kutatómunka anyagi támogatásban nem részesült.

Szerzői munkamegosztás: Az adatgyưjtésben, a kézirat megszövegezésében és áttekintésében valamennyi szerző részt vett. A cikk végleges változatát a szerzők elolvasták és jóváhagyták.

Érdekeltségek: A szerző́knek nincsenek érdekeltségeik.

\section{Irodalom}

[1] Evers, S., Marziniak, M.: Clinical features, pathophysiology, and treatment of medication-overuse headache. Lancet Neurol., 2010, 9(4), 391-401.

[2] Headache Classification Committee of the International Headache Society (IHS): The international classification of headache disorders, 3rd edition (beta version). Cephalalgia, 2013, 33(9), 629808 .

[3] Horton, B. T., Peters, G. A.: Clinical manifestations of excessive use of ergotamine preparations and management of withdrawal effect: Report of 52 cases. Headache, 1963, 2, 214-227.

[4] Kudrow, L.: Paradoxical effects of frequent analgesic use. Adv. Neurol., 1982, 33, 335-341.

[5] Saper, J. R.: Drug abuse among headache patients. In: Saper, J. R. (ed.): Headache disorders: Current concepts and treatment strategies. John Wright Publishing, Boston, 1983.

[6] Kaube, H., May, A., Pfaffenrath, V.: Sumatriptan. BMJ, 1994, 308(6943), 1573-1574.

[7] Zwart, J. A., Dyb, G., Hagen, K., et al.: Analgesic use: a predictor of chronic pain and medication overuse headache: the HeadHUNT Study. Neurology, 2003, 61(2), 160-164.

[8] Pascual, J., Colás, R., Castillo, J.: Epidemiology of chronic daily headache. Curr. Pain Headache Rep., 2001, 5(6), 529-536.

[9] Evers, S., Jensen, R.: Treatment of medication overuse headache - guideline of the EFNS headache panel. Eur. J. Neurol., 2011, $18(9), 1115-1121$.

[10] Katsarava, Z., Obermann, M.: Medication-overuse headache. Curr. Opin. Neurol., 2013, 26(3), 276-281.

[11] Linde, M., Gustavsson, A., Stovner, L. J., et al.: The cost of headache disorders in Europe: The Eurolight project. Eur. J. Neurol., 2012, 19(5), 703-711.

[12] Diener, H. C., Dablof, C. G.: Headache associated with chronic use of substances. In: Olesen, J., Tfelt-Hansen, P., Welch, K. M. A. (eds.): The headaches. 2nd ed. Lippincott, Williams \& Wilkins, Philadelphia, 1999.

[13] Evers, S., Suhr, B., Bauer, B., et al.: A retrospective long-term analysis of the epidemiology and features of drug-induced headache. J. Neurol., 1999, 246(9), 802-809.
[14] Wolfe, S., Van Stavern, G.: Characteristics of patients presenting with ocular pain. Can. J. Ophthalmol., 2008, 43(4), 432-434.

[15] Ertsey, Cs.: Headache in everyday medical practice. [Fejfájás a mindennapi orvosi gyakorlatban.] Lege Artis Medicinae, 2010, 20(11), 727-731. [Hungarian]

[16] Bigal, M. E., Serrano, D., Buse, D., et al.: Acute migraine medications and evolution from episodic to chronic migraine: a longitudinal population-based study. Headache, 2008, 48(8), 1157-1168.

[17] Ravishankar, K.: Medication overuse headache in India. Cephalalgia, 2008, 28(11), 1223-1226.

[18] Tepper, S. J.: Medication-overuse headache. Continuum (Minneap. Minn.), 2012, 18(4), 807-822.

[19] Katsarava, Z., Diener, H. C.: Medication overuse headache in Germany. Cephalalgia, 2008, 28(11), 1221-1222.

[20] Mathew, N. T., Kurman, R., Perez, F.: Drug induced refractory headache - clinical features and management. Headache, 1990, $30(10), 634-638$.

[21] Cupini, L. M., De Murtas, M., Costa, C., et al.: Obsessive-compulsive disorder and migraine with medication-overuse headache. Headache, 2009, 49(7), 1005-1013.

[22] Yoon, M. S., Manack, A., Schramm, S., et al.: Chronic migraine and chronic tension-type headache are associated with concomitant low back pain: results of the German Headache Consortium study. Pain, 2013, 154(3), 484-492.

[23] De Tommaso, M., Sardaro, M., Serpino, C., et al.: Fibromyalgia comorbidity in primary headaches. Cephalalgia, 2009, 29(4), 453-464.

[24] Yoon, M. S., Mueller, D., Hansen, N., et al.: Prevalence of facial pain in migraine: a population-based study. Cephalalgia, 2010, 30(1), 92-96.

[25] Plesh, O., Noonan, C., Buchwald, D. S., et al.: Temporomandibular disorder-type pain and migraine headache in women: a preliminary twin study. J. Orofac. Pain, 2012, 26(2), 91-98.

[26] Wilkinson, S. M., Becker, W. J., Heine, J. A.: Opiate use to control bowel motility may induce chronic daily headache in patients with migraine. Headache, 2001, 4l(3), 303-309.

[27] Paemeleire, K., Bahra, A., Evers, S., et al.: Medication-overuse headache in patients with cluster headache. Neurology, 2006, 67(1), 109-113.

[28] Radat, F., Creac'h, C., Swendsen, J. D., et al.: Psychiatric comorbidity in the evolution from migraine to medication overuse headache. Cephalalgia, 2005, 25(7), 519-522.

[29] Hagen, K., Linde, M., Steiner, T. J., et al.: Risk factors for medication-overuse headache: an 11-year follow-up study. The Nord Trøndelag Health Studies. Pain, 2012, 153(1), 56-61.

[30] Scher, A. I., Stewart, W. F., Ricci, J. A., et al.: Factors associated with the onset and remission of chronic daily headache in a population-based study. Pain, 2003, 106(1-2), 81-89.

[31] Cevoli, S., Sancisi, E., Grimaldi, D., et al.: Family history for chronic headache and drug overuse as a risk factor for headache chronification. Headache, 2009, 49(3), 412-418.

[32] Cevoli, S., Mochi, M., Scapoli, C., et al.: A genetic association study of dopamine metabolism-related genes and chronic headache with drug abuse. Eur. J. Neurol., 2006, 13(9), 1009-1013.

[33] Di Lorenzo, C., Di Lorenzo, G., Sances, G., et al.: Drug consumption in medication overuse headache is influenced by brain-derived neurotrophic factor Val66Met polymorphism. J. Headache Pain, 2009, 10(5), 349-355.

[34] Di Lorenzo, C., Sances, G., Di Lorenzo, G., et al.: The wolframin His611Arg polymorphism influences medication overuse headache. Neurosci. Lett., 2007, 424(3), 179-184.

[35] Cargnin, S., Viana, M., Ghiotto, N., et al.: Functional polymorphisms in COMT and SLC6A4 genes influence the prognosis of patients with medication overuse headache after withdrawal therapy. Eur. J. Neurol., 2014, 21(7), 989-995.

[36] De Felice, M., Ossipov, M. H., Porreca, F.: Update on medicationoveruse headache. Curr. Pain Headache Rep., 2011, 15(1), 79-83. 
[37] Srikiatkhachorn, A., Tarasub, N., Govitrapong, P.: Effect of chronic analgesic exposure on the central serotonin system: a possible mechanism of analgesic abuse headache. Headache, 2000, 40(5), 343-350.

[38] Coppola, G., Di Lorenzo, C., Schoenen, J., et al.: Habituation and sensitization in primary headaches. J. Headache Pain, 2013, 14, 65 .

[39] Coppola, G., Iacovelli, E., Bracaglia, M., et al.: Electrophysiological correlates of episodic migraine chronification: evidence for thalamic involvement. J. Headache Pain, 2013, 14, 76

[40] Riederer, F., Marti, M., Luechinger, R., et al.: Gray matter changes associated with medication-overuse headache: Correlations with disease related disability and anxiety. World J. Biol. Psychiatry, 2012, 13(7), 517-525.

[41] Ferraro, S., Grazzi, L., Mandelli, M. L., et al.: Pain processing in medication overuse headache: a functional magnetic resonance imaging (fMRI) study. Pain Med., 2012, 13(2), 255-262.

[42] Fumal, A., Laureys, S., Di Clemente, L., et al.: Orbitofrontal cortex involvement in chronic analgesic-overuse headache evolving from episodic migraine. Brain, 2006, 129(2), 543-550.

[43] Radat, F., Lanteri-Minet, M.: What is the role of dependencerelated behavior in medication-overuse headache? Headache, 2010, 50(10), 1597-1611.

[44] Peres, M. F., Mercante, J. P., Guendler, V. Z., et al.: Cephalalgiaphobia: a possible specific phobia of illness. J. Headache Pain, $2007,8(1), 56-59$

[45] Giannini, G., Zanigni, S., Grimaldi, D., et al.: Cephalalgiaphobia as a feature of high-frequency migraine: a pilot study. J. Head ache Pain, 2013, 14, 49.

[46] Fritsche, G., Frettlöh, J., Hüppe, M., et al.: Prevention of medication overuse in patients with migraine. Pain, 2010, 151(2), 404413.

[47] Cupini, L. M., De Murtas, M., Costa, C., et al.: Obsessive-compulsive disorder and migraine with medication-overuse headache. Headache, 2009, 49(7), 1005-1013.

[48] Grazzi, L., Usai, S., Prunesti, A., et al.: Behavioral plus pharmacological treatment versus pharmacological treatment only for chronic migraine with medication overuse after day-hospital withdrawal. Neurol. Sci., 2009, 30(Suppl. 1), S117-S119.

[49] Gunreben-Stempfle, B., Grießinger, N., Lang, E., et al.: Effectiveness of an intensive multidisciplinary headache treatment program. Headache, 2009, 49(7), 990-1000.

[50] Gyüre, T., Csépány, É., Hajnal, B., et al.: The Comprehensive Headache-related Quality of life Questionnaire shows significant improvement after withdrawal treatment in medication overuse headache: a pilot study. [Az Atfogó Fejfájással Kapcsolatos Életminőség-kérdőív szignifikáns javulást mutat a gyógyszertúlhasználattal társuló fejfájás kezelése után: próbavizsgálat.] Ideggyogy. Sz., 2014, 67(5-6), 169-176.

[51] Rossi, P., Jensen, R., Nappi, G., et al.: A narrative review on the management of medication overuse headache: the steep road from experience to evidence. J. Headache Pain, 2009, 10(6), $407-417$.

[52] Obermann, M., Katsarava, Z.: Management of medication-overuse headache. Expert Rev. Neurother., 2007, 7(9), 1145-1155.

[53] Pageler, L., Katsarava, Z., Diener, H. C., et al.: Prednisone vs. placebo in withdrawal therapy following medication overuse headache. Cephalalgia, 2008, 28(2), 152-156.
[54] Rabe, K., Pageler, L., Gaul, C., et al.: Prednisone for the treat ment of withdrawal headache in patients with medication overuse headache: a randomized, double-blind, placebo-controlled study. Cephalalgia, 2013, 33(3), 202-207.

[55] Diener, H. C., Katsarava, Z.: Analgesic/abortive overuse and misuse in chronic daily headache. Curr. Pain Headache Rep., 2001, 5(6), 545-550.

[56] Schwartz, T. H., Karpitskiy, V. V., Sohn, R. S.: Intravenous valproate sodium in the treatment of daily headache. Headache, 2002, 42(6), 519-522.

[57] Diener, H. C., Bussone, G., Van Oene, J. C., et al.: Topiramate reduces headache days in chronic migraine: a randomized, double-blind, placebo-controlled study. Cephalalgia, 2007, 27(7), 814-823.

[58] Silberstein, S. D., Lipton, R. B., Dodick, D. W., et al.: Efficacy and safety of topiramate for the treatment of chronic migraine: a randomized, double-blind, placebo-controlled trial. Headache, 2007, 47(2), 170-180.

[59] Munksgaard, S. B., Jensen, R. H.: Medication overuse headache. Headache, 2014, 54(7), 1251-1257.

[60] Silberstein, S. D., Blumenfeld, A. M., Cady, R. K., et al.: Onabotulinumtoxin A for treatment of chronic migraine: PREEMPT 24-week pooled subgroup analysis of patients who had acute headache medication overuse at baseline. J. Neurol. Sci., 2013, $331(1-2), 48-56$

[61] Grazzi, L., Andrasik, F., D'Amico, D., et al.: Behavioral and pharmacologic treatment of transformed migraine with analgesic overuse: outcome at 3 years. Headache, 2002, 42(6), 483-490.

[62] Gaul, C., van Doorn, C., Webering, N., et al.: Clinical outcome of a headache-specific multidisciplinary treatment program and adherence to treatment recommendations in a tertiary headache center: an observational study. J. Headache Pain, 2011, 12(4), 475-483.

[63] Wallasch, T. M., Kropp, P.: Multidisciplinary integrated headache care: a prospective 12 -month follow-up observational study. J. Headache Pain, 2012, 13(7), 521-529.

[64] Management of medication overuse headache. BMJ, 2010, 340, cl305.

[65] Katsarava, Z., Muessig, M., Dzagnidze, A., et al.: Medication overuse headache: rates and predictors for relapse in a 4 -year prospective study. Cephalalgia, 2005, 25(1), 12-15.

[66] Rossi, P., Faroni, J. V., Nappi, G.: Medication overuse headache: predictors and rates of relapse in migraine patients with low medical needs. A 1-year prospective study. Cephalalgia, 2008, 28(11), 1196-1200.

[67] Russell, M. B., Lundqvist, C.: Prevention and management of medication overuse headache. Curr. Opin. Neurol., 2012, 25(3), 290-295.

(Ertsey Csaba dr.,

Budapest, Balassa u. 6., 1083

e-mail: ertsey.csaba@med.semmelweis-univ.hu) 